\title{
EVALUATING VILLAGERS' LIFE SATISFACTION IN RESETTLEMENT COMMUNITY: A PILOT STUDY OF SUBURBAN NANJING, CHINA
}

\author{
Zhu Qian*
}

\begin{abstract}
This paper assesses displaced villagers' life satisfaction in government-designated resettlement communities after land expropriation. From the theoretical perspective of subjective well-being, the study explores the relationship between the overall life satisfaction of displaced villagers and their subjective satisfaction with three dimensions in their postresettlement life - 1) material living conditions, 2) social security and employment support, and 3) attitudinal perceptions, social relations and participation. A pilot survey was conducted in two resettlement communities in suburban Nanjing. The study shows that while compensation and resettlement policy reforms have improved resettled villagers' material living conditions; they still struggle with urban life transformation and adaptation from the social and attitudinal perspectives. An integrated resettlement approach is proposed to facilitate better accessibility to social security programs and non-agricultural employment opportunities, and to address issues in identity adaptation, lifestyle transformation, and social activity participation.
\end{abstract}

Keywords: Life Satisfaction, Resettlement, Land Expropriation, Displaced Villagers, China

\section{INTRODUCTION}

Rapid industrialization and massive urbanization in China's economic reform era has created enormous demand for urban construction land. The pace of urbanization has accelerated since the 1990s, leading to decrease in rural population decrease and loss of agricultural land due to urban development in rural land expropriation. An increasingly large number of rural villagers has been resettled to urbanized communities and lost all or part of their rural land during the process. Resettled villagers then have to face numerous challenges in their new urban life and often find themselves in a disadvantaged position in urban society. As passive participants in the process, resettled villagers typically have no alternative but to obey decisions from local authorities. Consequently, some resettled villagers may develop a resistant attitude towards resettlement policies and processes (Tang et al., 2016). Meanwhile, urban residents' perception of resettled villagers and the sense among villagers of being inferior to urban citizens formed by the long existing urban rural dualism might reinforce their limitations competing in the labour market and discourage their active participation in urban social activities (Zhang and Qian, 2020). Once deprived of their rural property rights and land collective ownership, resettled villagers encounter financial challenges in their daily life as well as face marginalization in the labour market and urban social security programs such as pension plans, health care, low-income subsidies, and unemployment insurance(Liang and Zhu, 2015; Ma and Hu. 2014). All these influence resettled villagers' attitudes toward compensation and resettlement policies and their overall life satisfaction with urban life.Over the past decade, multiple compensation and resettlement approaches have been devised to address these issues but with mixed consequences.

Existing empirical studies on resettled villager's well-being have not sufficiently addressed whether resettled villagers consider policy reforms effective and how they evaluate their life quality and well-being after land expropriation and resettlement. Research on resettled villagers' life satisfaction in urban society from their own opinions will contribute to local government's understanding and planning of resettlement programs in their policy revisions. It will also provide an opinion platform to resettled villagers and facilitate a bottom-up mechanism in assessing resettlement and compensation systems to give more considerations to the rights and interests that resettled villagers care about. It is imperative to investigate how resettled villager's life has been impacted by resettlement and compensation programs and how (un)satisfied these former villagers feel about the resettlement and compensation institution in bettering their life experience in urban setting.

* Prof. Zhu (Joe) Qian, Associate Professor, School of Planning, University of Waterloo, Canada. Email Correspondence: z3qian@uwaterloo.ca 
China's compensation principles are focused mainly on direct economic loss, leaving insufficient considerations to indirect losses association with rural land conversion to urban uses such as agricultural and environmental amenity changes, new urban life assistance, tradition and culture transformation, and lifestyle changes ( $\mathrm{Ma}$ and $\mathrm{Hu}, 2014$ ). Yet, resettled villagers' life quality after land expropriation can experience tremendous changes resulted from material living conditions, social security coverage, re-employment, social network reconstruction and urban lifestyle adaptation.Studies have examined various aspects of resettled villagers' satisfaction with their life quality (Chen et al., 2013; Duan and Chen, 2009; Hu et al., 2014;Luo and Fan, 2008) but few have employed the perspective of subjective well-being and incorporated multiple dimensions to assess resettled villagers' satisfaction level with new urban life from their own opinions. The subjective well-being discourse emphasizes on individual's own evaluation that can be cognitive, experiential, and attitudinal (Diener, 2000). This research examines the practicability and sustainability of resettlement and compensation programs by investigating resettled villagers' self-assessment of life quality and wellbeing in their resettlement communities designated by local government. Life quality satisfaction assessment serves to provide more empirical evidence of how resettled villagers evaluate their life quality, and clarify what life aspects they are satisfied or unsatisfied with, and understand what they really expect and highly value in current resettlement and compensation institutions.

\section{CONCEPTUAL DISCOURSE ON SUBJECTIVE WELL-BEING AND RESETTLEMENT}

Subjective well-being theory is central to life quality research. Life quality refers to the overall well-being of individuals and is typically defined by multiple value-based indicators such as equal distribution of resources, living standards, access to employment opportunities, and social security systems (Bellani and Ambrosio, 2011; Bohnke, 2005). It entails material conditions, social relationships and participation, subjective satisfaction perception, and psychological experience (Bohnke, 2005; Diener, 2000). Allardt (1993) summarizes life quality in a three-pillar concept of 'having, loving and being' in which 'having' refers to material living conditions, 'loving' refers to social relationship networks, and 'being' refers to a sense of belonging and recognition as well as integration into the new society. Besides material conditions, subjective wellbeing also considers social interactions and psychological factors such as attitudes and perceptions.
Subjective well-being theory concerns about individual's self-reported satisfaction with multiple dimensions of life quality (Bohnke, 2005; Diener et al., 2003). From the subjective well-being perspective, life satisfaction can be assessed in three dimensions: 1) material living conditions, 2) social security and employment support, and 3) attitudinal perceptions, social relationships and participation. Each of the three dimensions may exert influence on other dimension(s). Factors in material living conditions include living environment, income, expenditure, consumption capability, and disposal of monetary compensation from land expropriation; factors in social security and employment support include social security types, coverage, professional skill training, employment information availability and accessibility; factors in social relationships, participation, and attitudinal perceptions include participation in community activities, knowledge of compensation policies obtained by social interactions, attitudes toward urban life, and use of social networks.

Subjective well-being has been strongly influenced by material living conditions (Bohnke, 2005), Material living conditions relate to financial burden, consumption capability, and living environment (Bellani and Ambrosio, 2011). Substantial relationships exist between a variety of influencing factors of material living conditions and people's selfreported satisfaction (Bayram et al., 2012; Bohnke, 2005; Liu, He and Wu, 2008; Shui et al., 2014). Typically, those with limited access to the labour market are more vulnerable to unemployment risks and insufficient social security system (Silver, 1994). Long-term unemployment means not only depletion of income and material sources, but also loss of social status, self-identity, and social network (Bohnke, 2005). For social relationships and attitudinal perceptions, research has found that active participation in social interactions, either formal or informal, is positively related to life well-being and happiness (Helliwell, 2001; Putnam, 2001). Displaced villagers usually are faced with challenges in self-identity recognition and adaptation to urban life (Zhang and Tong, 2006), because of factors such as institutional inequality and attitudinal perception of rural being inferior than urban (Wu and Qin, 2008). Some displaced villagers still consider themselves as traditional rural villagers in psychological, cultural and social aspects, despite of their urban household registration status (Liang and Zhu, 2015).

\section{RESEARCH METHODOLOGY}

Since the 2000s, Nanjing has witnessed two major resettlement and compensation policy reforms, aiming to improve displaced villagers' life quality and experience in 
urban society. The 2004 policy reform tremendously increased compensation rates and diversified approaches, in order to provide resettled villagers with better living standard (Zhou et al., 2014). For instance, monthly monetary compensation replaced the lump-sum compensation payment. About $70 \%$ of the compensation and resettlement fund went directly to displaced villagers' personal accounts instead of their rural collective's. However, the 2004 policy reform did not grant resettled villagers the same social security package that was enjoyed by urban residents. The 2011 policy reform introduced a social security fund and a wide range of social insurances for resettled villagers' long-term social welfare. It also ushered in a comprehensive compensation mechanism that is based on a zoning compensation system, an advanced social security arrangement (such as endowment insurance, health care, and unemployment insurance), and a resettlement fund. The compensation standard takes location and differential land rent into consideration, in which rural land is classified into three acquisition zones with differentiated acquisition and compensation prices. Compensation rateswere also raised from the 2004 standards.

The case study was conducted in two urban fringe sites in Nanjing - Tiexinqiao and Longtan, which are located respectively in south and north to the city core. Both sites accommodate resettled villagers in government-designated resettlement communities. Tiexinqiao was built in the early 2000s and Longtanin the mid to later 2000s. Tiexinqiao is closer to the city center than Longtan. Structured survey was conducted during March and May 2017. Among ninety eight valid questionnaire returns, fifty five were from Tiexinqiao (Chunjiang New Community) and forty three were from Longtan (Longtan Community). Sampling participants were randomly selected and survey unit was resettled villager household. The survey questionnaire includes five categories: economic and living environment indicators representing the dimension of material living conditions; social security coverage and employment situation indicators representing the dimension of social security and employment support; and indicators represent the dimension of social relationships, participation and attitudinal perceptions. A Like Scale was used ranging from 1 for very unsatisfied, 2 for partly unsatisfied, 3 for neutral, 4 for partly satisfied, to 5 for very satisfied; or 1 for strongly agree, 2 for partly agree, 3 for neutral, 4 for partly disagree, 5 for strongly disagree. This study used an ordinal logistic model to assess life satisfaction, expressed in two equations:

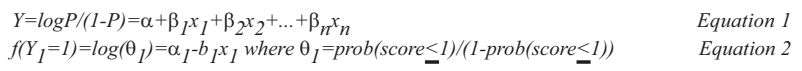

$\mathrm{P}$ represents the probability of resettled villagers' life satisfaction scale, qualitative variable, or a variable with a binary feature after linearization. Resettled villager household's life satisfaction is classified into five levels from very unsatisfied, partly satisfied, neutral, partly satisfied to very satisfy. Given $\mathrm{P}$ as the probability that a resettled villager household issatisfied and the probability of unsatisfied is ' $1-\mathrm{P}$ ', $0<\mathrm{P}<1$. Let $\alpha$ be the constant value, $X_{n}$ are independent variables that denote various factors influencing resettled villagers' satisfaction level, and $\beta_{n}$ is the partial regression coefficient in the logistic regression (Table 1).

Table-1: Define latent and explanatory variables with 24 variables.

\begin{tabular}{|c|c|c|c|}
\hline Variable & Define Variable & Assigned Value of Variables & Mean \\
\hline Y1 & Satisfaction level with overall life quality & $\begin{array}{l}1=\text { very unsatisfied, } 2=\text { partly unsatisfied, } \\
3=\text { neutral, } 4=\text { partly satisfied, } 5=\text { very satisfied }\end{array}$ & 2.52 \\
\hline Y2 & $\begin{array}{l}\text { Satisfaction level with compensation standard } \\
\text { and approach }\end{array}$ & $\begin{array}{l}1=\text { very unsatisfied, } 2=\text { partly unsatisfied } \\
3=\text { neutral, } 4=\text { partly satisfied, } 5=\text { very satisfied }\end{array}$ & 2.38 \\
\hline Y3 & $\begin{array}{l}\text { Satisfaction level with material living } \\
\text { conditions }\end{array}$ & $\begin{array}{l}1=\text { very unsatisfied, } 2=\text { partly unsatisfied } \\
3=\text { neutral, } 4=\text { partly satisfied, } 5=\text { very satisfied }\end{array}$ & 2.33 \\
\hline Y4 & Satisfaction level with social security & $\begin{array}{l}1=\text { very unsatisfied, } 2=\text { partly unsatisfied, } \\
3=\text { neutral, } 4=\text { partly satisfied, } 5=\text { very satisfied }\end{array}$ & 2.43 \\
\hline Y5 & Satisfaction level with employment support & $\begin{array}{l}1=\text { very unsatisfied, } 2=\text { partly unsatisfied, } \\
3=\text { neutral, } 4=\text { partly satisfied, } 5=\text { very satisfied }\end{array}$ & 2.00 \\
\hline $\mathrm{X} 1$ & Age & $1=18-30,2=31-45,3=46-60,4=61-70,5=>70$ & 3.33 \\
\hline $\mathrm{X} 2$ & Education level & $\begin{array}{l}1=\text { elementary school and below, } 2=\text { middle school, } \\
3=\text { equal to high school, } 4=\text { college and above }\end{array}$ & 1.81 \\
\hline $\mathrm{X} 3$ & Work status before and after acquisition & $\begin{array}{l}1=\text { agricultural sector, } 2=\text { private industry, } 3= \\
\text { migrant worker, } 4=\text { self-employed, } 5= \\
\text { government/government-owned enterprise, } 6= \\
\text { student, } 7=\text { unemployed, } 8=\text { retirement }\end{array}$ & $\begin{array}{l}\text { before: } \\
1.64 \\
\text { after: } \\
5.60\end{array}$ \\
\hline
\end{tabular}




\begin{tabular}{|c|c|c|c|}
\hline Variable & Define Variable & Assigned Value of Variables & Mean \\
\hline $\mathrm{X} 4$ & Length (year) of resettlement & before $2004=1,2004-2011=2$, after $2011=3$ & 1.67 \\
\hline X5 & Change in monthly income & $\begin{array}{l}1=\text { significantly decrease, } 2=\text { decrease, } 3=\text { similar, } \\
4=\text { increase, } 5=\text { significantly increase }\end{array}$ & 3.63 \\
\hline $\mathrm{X} 6$ & Change in monthly expense & $\begin{array}{l}1=\text { significantly decrease, } 2=\text { decrease, } 3=\text { similar, } \\
4=\text { increase, } 5=\text { significantly increase }\end{array}$ & 4.41 \\
\hline $\mathrm{X} 7 \mathrm{a}$ & Overall living environment & $\begin{array}{l}1=\text { worse than before, } 2=\text { generally similar, } \\
3=\text { better than before, } 0=\text { not sure }\end{array}$ & 1.99 \\
\hline $\mathrm{X} 7 \mathrm{~b}$ & Housing area & $\begin{array}{l}1=\text { worse than before, } 2=\text { generally similar, } \\
3=\text { better than before, } 0=\text { not sure }\end{array}$ & 1.52 \\
\hline $\mathrm{X} 7 \mathrm{c}$ & Housing quality & $\begin{array}{l}1=\text { worse than before, } 2=\text { generally similar, } \\
3=\text { better than before, } 0=\text { not sure }\end{array}$ & 1.86 \\
\hline$X 7 d$ & Utility facilities & $\begin{array}{l}1=\text { worse than before, } 2=\text { generally similar, } \\
3=\text { better than before, } 0=\text { not sure }\end{array}$ & 1.99 \\
\hline $\mathrm{X} 7 \mathrm{e}$ & Transportation services & $\begin{array}{l}1=\text { worse than before, } 2=\text { generally similar, } \\
3=\text { better than before, } 0=\text { not sure }\end{array}$ & 2.48 \\
\hline $\mathrm{X} 7 \mathrm{f}$ & Community safeguard & $\begin{array}{l}1=\text { worse than before, } 2=\text { generally similar, } \\
3=\text { better than before, } 0=\text { not sure }\end{array}$ & 2.18 \\
\hline $\mathrm{X} 7 \mathrm{~g}$ & Telecommunication services & $\begin{array}{l}1=\text { worse than before, } 2=\text { generally similar, } \\
3=\text { better than before, } 0=\text { not sure }\end{array}$ & 2.33 \\
\hline $\mathrm{X} 7 \mathrm{~h}$ & Convenience and richness of daily activities & $\begin{array}{l}1=\text { worse than before, } 2=\text { generally similar, } \\
3=\text { better than before, } 0=\text { not sure }\end{array}$ & 2.47 \\
\hline $\mathrm{X} 8$ & $\begin{array}{l}\text { Satisfaction level with endowment social } \\
\text { insurance }\end{array}$ & $\begin{array}{l}1=\text { very unsatisfied, } 2=\text { partly unsatisfied, } 3= \\
\text { neutral, } 4=\text { partly satisfied, } 5=\text { very satisfied }\end{array}$ & 2.24 \\
\hline X9 & $\begin{array}{l}\text { Satisfaction level with urban health-care } \\
\text { insurance }\end{array}$ & $\begin{array}{l}1=\text { very unsatisfied, } 2=\text { partly unsatisfied, } 3= \\
\text { neutral, } 4=\text { partly satisfied, } 5=\text { very satisfied }\end{array}$ & 2.26 \\
\hline $\mathrm{X} 10$ & $\begin{array}{l}\text { Satisfaction level with new rural cooperative } \\
\text { health-care insurance }\end{array}$ & $\begin{array}{l}1=\text { very unsatisfied, } 2=\text { partly unsatisfied, } 3= \\
\text { neutral, } 4=\text { partly satisfied, } 5=\text { verysatisfied }\end{array}$ & 2.97 \\
\hline $\mathrm{X} 11$ & $\begin{array}{l}\text { Satisfaction level with unemployment } \\
\text { insurance }\end{array}$ & $\begin{array}{l}1=\text { veryunsatisfied, } 2=\text { partly unsatisfied, } 3= \\
\text { neutral, } 4=\text { partly satisfied, } 5=\text { verysatisfied }\end{array}$ & 1.00 \\
\hline $\mathrm{X} 12$ & $\begin{array}{l}\text { Whether vocational training was offered or } \\
\text { funded by town government or rural collective }\end{array}$ & $1=$ Yes, $0=$ No & 0.15 \\
\hline $\mathrm{X} 13$ & Whether it was helpful or necessary & $1=$ Yes, $0=$ No & 0.19 \\
\hline $\mathrm{X} 14$ & $\begin{array}{l}\text { Do you have organizational access to job } \\
\text { market information }\end{array}$ & $1=$ Yes, $0=$ No & 0.18 \\
\hline $\mathrm{X} 15$ & $\begin{array}{l}\text { Do you receive government assistance for } \\
\text { employment }\end{array}$ & $1=$ Yes, $0=$ No & 0.42 \\
\hline $\mathrm{X} 16$ & $\begin{array}{l}\text { Feel hard to adapt to urban lifestyle and } \\
\text { environment }\end{array}$ & $\begin{array}{l}1=\text { strongly agree, } 2=\text { partly agree, } 3=\text { neutral, } \\
4=\text { partly disagree }, 5=\text { strongly disagree }\end{array}$ & 2.38 \\
\hline $\mathrm{X} 17$ & Prefer rural housing and living environment & $\begin{array}{l}1=\text { stronglyagree, } 2=\text { partly agree, } 3=\text { neutral, } \\
4=\text { partly disagree, } 5=\text { strongly disagree }\end{array}$ & 2.02 \\
\hline $\mathrm{X} 18$ & $\begin{array}{l}\text { Prefer farming lifestyle and feel } \\
\text { psychologically close to land }\end{array}$ & $\begin{array}{l}1=\text { stronglyagree, } 2=\text { partly agree, } 3=\text { neutral, } \\
4=\text { partly disagree, } 5=\text { strongly disagree }\end{array}$ & 2.35 \\
\hline $\mathrm{X} 19$ & $\begin{array}{l}\text { Expect better living quality and security with } \\
\text { rural land }\end{array}$ & $\begin{array}{l}1=\text { stronglyagree, } 2=\text { partly agree, } 3=\text { neutral }, \\
4=\text { partly disagree, } 5=\text { strongly disagree }\end{array}$ & 1.54 \\
\hline $\mathrm{X} 20$ & $\begin{array}{l}\text { Prefer to keep rural registration status and } \\
\text { land rather than receive any compensation }\end{array}$ & $\begin{array}{l}1=\text { strongly agree, } 2=\text { partly agree, } 3=\text { neutral, } \\
4=\text { partly disagree, } 5=\text { strongly disagree }\end{array}$ & 2.48 \\
\hline $\mathrm{X} 21$ & $\begin{array}{l}\text { Reduce frequency to contact with old friends } \\
\text { and relatives }\end{array}$ & $\begin{array}{l}1=\text { strongly agree, } 2=\text { partly agree, } 3=\text { neutral }, \\
4=\text { partly disagree, } 5=\text { strongly disagree }\end{array}$ & 2.38 \\
\hline $\mathrm{X} 22$ & $\begin{array}{l}\text { Add frequency to meet with new friends and } \\
\text { neighbors }\end{array}$ & $\begin{array}{l}1=\text { strongly disagree, } 2=\text { partly disagree, } 3= \\
\text { neutral, } 4=\text { partly agree, } 5=\text { strongly agree }\end{array}$ & 3.17 \\
\hline $\mathrm{X} 23$ & $\begin{array}{l}\text { Participation in community activities and } \\
\text { development }\end{array}$ & $\begin{array}{l}1=\text { strongly disagree, } 2=\text { partly disagree, } 3= \\
\text { neutral, } 4=\text { partly agree, } 5=\text { strongly agree }\end{array}$ & 2.58 \\
\hline $\mathrm{X} 24$ & $\begin{array}{l}\text { Awareness of public notice about } \\
\text { relevant compensation policies }\end{array}$ & $\begin{array}{l}\text { ely concern, } 2=\text { know a little bit, } 3=\text { somewhat } \\
\text { ar, } 4=\text { fully knowledgeable, } 0=\text { no policy notice }\end{array}$ & 1.68 \\
\hline
\end{tabular}




\section{RESEARCH FINDINGS}

\section{Descriptive Analysis}

Among the ninety eight resettled villagers, sixty were male and thirty eight were female, with a mean age of fifty one years old. $84.5 \%$ of these resettled villagers already converted their rural household registration status to urban, sponsored by the local government. The status made them eligible for urban social security welfare. More than half of these surveyed villagers were resettled before 2004, and only about $10.7 \%$ were relocated after the 2011 policy reform, leaving the rest displaced in the years between 2004 and 2011. Resettled villagers with elementary school education or illiterate had the largest share (46.6\%), and those with college/university education or above only had a mere share of $4.8 \%$. Before land expropriation, $73.8 \%$ of resettled villagers worked in agricultural sector, and $9.7 \%$ were in local private industries, $6.8 \%$ seasonal migrant workers, $7.8 \%$ self-employed, and only $1.9 \%$ in government or town and village enterprises (TVEs). After resettlement, 43.6\% of resettled villagers chose to retire (which was well reflected by the median age of 51 in the survey), $22.8 \%$ were in local private industries, $10.9 \%$ were small business owners. Resettlement changed villagers' employment and many were pushed to work in non-agricultural sectors or become unemployed. The employment changes were closely related to educational attainment - none of those with post-secondary or higher education attainment, typically young- and middleaged, engaged in agricultural work prior to land expropriation.

After land expropriation, more than $60.0 \%$ of resettled villagers were unsatisfied with their material living conditions, and more than $70.0 \%$ of resettled villagers expressed strong dissatisfaction with their current employment situations, while only $11.4 \%$ held a positive attitude toward life quality. On one hand, about $90.4 \%$ of resettled villagers who felt dissatisfied with their overall life quality also expressed dissatisfaction about their material living conditions. About $88.5 \%$ of resettled villagers who felt dissatisfied with their overall life quality also expressed dissatisfaction about social security programs, and $73.1 \%$ of resettled villagers who felt dissatisfied with their overall life quality also expressed dissatisfaction about employment assistance from the local government. On the other hand, among those who were satisfied with their overall life quality, $63.9 \%$ showed a positive attitude toward material living conditions, and $66.7 \%$ were satisfied with social security programs, but only $11.1 \%$ appeared to feel satisfied with employment assistance from the local government.
Among various compensation approaches, monetary compensation was the dominant one in all resettlement cases. About $41.6 \%$ of resettled villagers also received inkind apartment unit compensation, and $31.7 \%$ of resettled villagers received social insurance such as endowment fund, health care, unemployment insurance and/or low-income subsidies. Only $2.0 \%$ of resettled villagers agreed that they received employment arrangement or vocational training as part of their compensation package.

Resettled villagers shared common choices in spending their monetary compensation fund $-45.5 \%$ of them used most of the compensation fund to purchase discounted apartment units exclusively available for them, and 30.7\% of them used part of the compensation fund for furniture and interior decoration. About $24.8 \%$ of resettled villagers chose to use part of the compensation fund to purchase social security package. Only $11.9 \%$ of resettled villagers were able to reserve some monetary compensation for financial investment. While about $55.6 \%$ of resettled villagers reported that their monthly income increased after land expropriation, all surveyed villagers complained that their monthly expenditure grew significantly after land expropriation.

Among about $40.8 \%$ of resettled villagers indicated that they were satisfied with living environment, most of whom lived in Longtan, while about $37.8 \%$ of resettled villagers expressed very low satisfaction with living environment, most of whom lived in Tiexinqiao. In-kind apartment unit was part of the compensation package, the average area of in-kind apartment unit floor area was $103 \mathrm{~m}^{2}$ before 2004, $114 \mathrm{~m}^{2}$ between 2004 and 2011, and $246 \mathrm{~m}^{2}$ after 2011 . About $74.0 \%$ of resettled villagers were allocated only one apartment unit; almost all of them received the compensation before 2011. Those households that received more than three apartment units were typically resettled after 2011. A few villagers resettled after 2011 in Longtan admitted that they received several apartment units as part of their compensation packages. While the total floor areas of these multiple units were large, each unit's floor area was insufficient to accommodate a traditionally large household of five to six family members. Therefore, many resettled households preferred to have large-sized apartment units.

Resettled villagers demonstrated improved satisfaction with social insurance policy. About $70.0 \%$ of the villagers who were resettled before 2004 expressed strong dissatisfaction with their social security arrangement. About $66.7 \%$ of the villagers who were relocated after 2004 felt partly satisfied or very satisfied with their social security arrangement. 
Among those who were displaced after 2011, almost 80.0\% of them were at least partly satisfied with their social security package. About $80.6 \%$ of resettled villagers reported that they were covered by endowment social insurance programs, $87.8 \%$ of resettled villagers claimed that they were covered by urban health care. However, only $23.5 \%$ of these surveyed were covered by unemployment insurance. The survey demonstrates the lack of employment assistance programs in both communities. Only $14.6 \%$ of resettled villagers received vocational training after land expropriation, and $11.7 \%$ of resettled villagers agreed that the vocational training was supported by local township administration. Many resettled villagers opted out training workshops for various reasons such as age, time and financial restrictions, course contents, and lack of practical objectives of training programs. A few villagers found the vocational training that they received from the local government was not helpful in finding a position in the job market. Instead, those who chose to attend technical skill related training programs by themselves found them helpful. Social capital and social media played important roles in resettled villagers' job seeking. About $30.6 \%$ of surveyed villagers admitted that they relied on social networks of relatives and friends in finding jobs and social media was also widely used in finding jobs (39.8\%). The conventional way of resorting to employment intermediary agencies became less popular (16.3\%). Close to $60.0 \%$ of resettled villagers groused about receiving little assistance from government in their searching for employment.

Social participation was reflected by villagers' intention to involve in community activities and their engagement in community development. Resettled villagers' awareness of compensation and resettlement policies was also an indication of their social participation. Up to $55.4 \%$ of resettled villagers showed little interest in community affairs and activities and $55.1 \%$ of villagers had very limited knowledge of compensation and resettlement related policies. When asked about their interactions with others, $60.0 \%$ of resettled villagers admitted that they reduced contacts with rural relatives, neighbours, and friends after resettlement.
Meanwhile, $52.0 \%$ of resettled villagers became acquainted with new neighbours and friends after resettlement. A large share of resettled villagers showed a strong inclination to rural living environment and lifestyle - about $60.0 \%$ of villagers claimed that they would rather give up their new urban household registration status and compensation package in exchange for their (lost) rural land.

\section{Ordinal Regression Analysis}

Cronbach's Alpha reliability analysis was performed to test independent variables in order to examine whether the multiple questions measure a same dependent variable. The Cronbach's Alpha of each dimension is summarized in Table 2. The negative Alpha value for personal socioeconomic attributes was calculated from a negative average covariance among the variables, which was against the assumption of the reliability model. This was because of a non-consistent scale of measurement among the variables (X1-X4). It indicates that these variables did not have good fitness when being incorporated into a regression model. However, it does not mean this dimension had little importance to life satisfaction assessment. All values in Table 4 indicate a high level of internal consistency. But the factors of personal socioeconomic attributes and employment support appeared to be not correlated or consistent. Therefore, these variables may not have good fitness in measuring resettled villagers' satisfaction in a continuous regression model.

Table 3 shows that the overall life quality was positively correlated with the material living condition and social security dimensions, with a significance value lower than 0.01 . The overall life quality seems less relevant to the employment dimension and the significance value did not support a convincible statistical relationship between the two. The dimension of material living conditions was closely correlated to the social security dimension and the employment dimension. In addition, there was significant relationship between the social security and the employment dimensions. All discussed positive relationships were accepted with a high significance level ( $p$-value $<0.05)$.

Table-2: Alpha reliability analysis of influencing factor clusters.

\begin{tabular}{|l|c|c|}
\hline Influencing Factors & Cronbach's Alpha & N of Variables \\
\hline Personal socioeconoic attributes & Negative & X1 - X4 \\
\hline Material living conditions & 0.681 & X7a - X7h \\
\hline Living environment & 0.747 & X8 - X11 \\
\hline Social security & 0.739 & X12-X15 \\
\hline Employment support & 0.392 & X16-X24 \\
\hline Perceptive and social dimension & 0.828 & \\
\hline
\end{tabular}


Table-3: Correlations between life quality satisfaction and levels of satisfactions in sub-dimensions.

\begin{tabular}{|l|l|c|c|c|c|}
\hline \multicolumn{2}{|c|}{ Correlations } \\
\hline \multirow{2}{*}{ Y1: Life Qality } & Y1: Life Quality & $\begin{array}{c}\text { Y3: Material } \\
\text { Conditions }\end{array}$ & $\begin{array}{c}\text { Y4: Social } \\
\text { Security }\end{array}$ & $\begin{array}{c}\text { Y5: } \\
\text { Employment }\end{array}$ \\
\hline \multirow{3}{*}{ Y3: Material Conditions } & Pearson Correlation & 1 & $0.720^{* *}$ & $0.663^{* *}$ & 0.193 \\
\cline { 2 - 6 } & Sig. (2-Tailed) & & 0.000 & 0.000 & 0.058 \\
\cline { 2 - 6 } & Pearson Correlation & & 1 & $0.684^{* *}$ & $0.319^{* *}$ \\
\hline \multirow{3}{*}{ Y4: Social Security } & Sig. (2-Tailed) & & & 0.000 & 0.001 \\
\cline { 2 - 6 } & Pearson Correlation & & & 1 & $0.347^{*}$ \\
\cline { 2 - 6 } & Sig. (2-Tailed) & & $0.319^{* *}$ & $0.347^{* *}$ & 1 \\
\hline \multirow{2}{*}{ Y5: Employment } & Pearson Correlation & 0.193 & 0.001 & 0.000 & \\
\cline { 2 - 6 } & Sig. (2-Tailed) & 0.058 & & & \\
\hline ** Correlation is significant at the 0.01 level (2-tailed). & & & & \\
\hline
\end{tabular}

The analysis using the ordinal logit model for the overall life quality shows that the satisfaction with material living conditions and social security had a positive influence on the overall life satisfaction. The dimension of material living conditions was a stronger contribution to villagers' life quality satisfaction than the social security dimension. Ordinal logit model regression can also be conducted for material living conditions, social security and employment support, as well as social relationships, participation, and attitudinal perceptions to reveal more detailed relationships. For instance, resettled villagers' frequency in interacting with their rural relatives, friends and neighbours, and their preference for rural lifestyle and traditional attachment to rural land indicated that the more they cling to their rural lifestyle, the lower their overall life quality satisfaction was.

\section{CONCLUSION}

The study shows that resettled villagers' higher adaptation capability in living in urban environment and less preference for rural lifestyleand rural amenity can facilitate their satisfaction with various aspects in urban living. Several policy implications can be proposed. First, reformed compensation and resettlement should give consideration to both economic well-being and non-economic aspects to reflect the multifunction of rural land that is lost to urbanization. Second, compensation and resettlement approaches can include more alternatives for employment support, extended endowment security insurance and health care insurance.Unemployment insurance coverage needs to be expanded so that more resettled villagers can benefit from the programs. Third, local government,in collaboration with non-government interests, needs to pay more attention to resettlement community management to address concerns in housing conditions, public facilities, community safety, and community activities to create a better living experience for resettled villagers.

\section{REFERENCES}

Allardt, E., 1993, "Having, Loving, Being: An Alternative to the Swedish Model of Welfare Research", The Quality of Life, 8, 88-95.

Bayram, N., Aytac, S., Aytac, M., Sam, N., and Bilgel, N., 2012, Poverty, Social Exclusion and Life Satisfaction: A Study from Turkey, “Journal of Poverty", 16(4), 375-391.

Bellani, L., and D'Ambrosio, C., 2011, Deprivation, Social Exclusion and Subjective Well-Being, "Social Indicators Research", 104(1), 67-86. 
Bohnke, P., 2005, First European Quality of Life Survey: Life Satisfaction, Happiness and Sense of Belonging. Office for Official Publications in the European Communities.

Chen, D., Tang, K. K., Zhao, L., and Zhang, Y., 2013, "Will China's Cooperative Medical System Fail Again? Insight from Farmer Satisfaction Survey, Health Promotion International, 30(2), 251-261.

Diener, E., 2000, "Subjective Well-Being: The Science of Happiness and a Proposal for a National Index", American Psychologist, 55(1), 34 .

Diener, E., Oishi, S., and Lucas, R. E., 2003, Personality, Culture, and Subjective Well-Being: Emotional and Cognitive Evaluations of Life, Annual review of psychology, 54(1), 403-425.

Duan, J. H., and Chen, J. B., 2009, "Statistical Investigation and Analysis on Satisfaction Degree of Chinese Urban and Rural People", Statistics and Information Forum, 24(4), 79-84 (in Chinese).

Helliwell, J., 2001, "Social Capital, the Economy and Well-Being", The Review of Economic Performance and Social Progress, in: Andrew Sharpe and Keith Banting, Di (ed.), The Review of Economic Performance and Social Progress 2001: The Longest Decade: Canada in the 1990s, Volume 1 Centre for the Study of Living Standards, The Institute for Research on Public Policy.

Hu, W., Zhang, X., Song, Y., Shen, L., Liu, J., and Zhang, A., 2014, “Life Satisfaction Approach to Farmers' Compensation for Land Acquisition: Empirical Study from the Suburbs of Wuhan City", Chinese Journal of Population Resources and Environment, 12(4), 316-323.

Liang, Y., and Zhu, D., 2015, "Subjective Well-Being of Chinese Landless Peasants in Relatively Developed Regions: Measurement using PANAS and SWLS”, Social Indicators Research, 123(3), 817-835.

Liu, Y., He, S., and Wu, F., 2008, “Urban Pauperization Under China's Social Exclusion: A Case Study of Nanjing”, Journal of Urban Affairs, 30(1), 21-36.

Luo, Y. M., and Fan, L. M., 2008, The Economic Effects of Rural Infrastructure and Farmers' Satisfaction Research Based on 44 Administrative Village in Shandong Province, Inquiry on Economic Issue, 12, 67-73 (in Chinese).

Ma, K., and Hu, L., 2014, "The Research of Landless Peasants Social Risks Management Which is Based on the Perspective of Social Security”, International Integration for Regional Public Management (ICPM), 126-130. Atlantis Press.

Putnam, R., 2001, "Social Capital: Measurement and Consequences", Canadian Journal of Policy Research, 2(1), 41-51.

Silver, H., 1994, “Social Exclusion and Social Solidarity: Three Paradigms”, International Labour Review, 133, 531-578.

Shui, W., Bai, J., Zhang, S., and Chen, Y., 2014, “Analysis of the Influencing Factors on Resettled Farmer's Satisfaction under the Policy of the Balance between Urban Construction Land Increasing and Rural Construction Land Decreasing: A Case Study of China's Xinjin County in Chengdu City", Sustainability, 6(12), 8522-8535.

Tang, S., Hao, P., and Huang, X., 2016, "Land Conversion and Urban Settlement Intentions of the Rural Population in China: A case study of suburban Nanjing", Habitat International, 51, 149-15.

Wu, S., and Qin, Q., 2008, Research Progress of the Identity Recognition of Land-Lost Farmers During the Process of Urbanization", Journal of Anhui Agricultural Sciences, 36(23), 193-196 (in Chinese).

Zhang, H. and Tong, X., 2006, "Self-Identity of the Passive-Urbanized Group in the Process of Obtaining Urban Adaptability and Modernity: An Empirical Study on 561 Land-Displaced Peasants in Nanjing”, Sociological Studies, 2, 84-106.

Zhang, S. and Qian, Z., 2020, Villagers' acculturation in China's land expropriation-induced resettlement neighborhood: A Shanghai case. International Journal of Intercultural

Relations, 74, pp.174-188.

Zhou, J., Yao, P., Xu, L., and Chen, Z., 2014, Land Requisition System Reform on the Background of Urban-Rural Integration: Reform Practice and Performance of Nanjing", Modern City Studies, 08, 25-30 (in Chinese). 